\title{
A RECUPERAÇÃO JUDICIAL DE EMPRESAS
}

\author{
THE JUDICIAL REORGANIZATION OF COMPANIES
}

Tarcisio Teixeira*

\begin{abstract}
Resumo:
O presente artigo trata da recuperação judicial de empresas a partir da doutrina empresarialista, da Lei n. 11.101/2005 e da jurisprudência brasileira. Verifica que a recuperação judicial é uma das espécies de recuperação de empresas, bem como que o princípio da preservação da empresa tem sido o grande norteador da doutrina e jurisprudência, especialmente quando se trata de firmar-se no sentido da prevalência do interesse coletivo em detrimento de interesses individuais. Analisa o regime jurídico da recuperação judicial, passando pelos aspectos da natureza jurídica, pressupostos, créditos abrangidos, requisitos e meios de recuperação; para então examinar o plano de recuperação e sua viabilidade econômica e aprovação. Por último, verifica-se a possibilidade de recuperação judicial às empresas rurais e às cooperativas, bem como a recuperação especial das microempresas e empresas de pequeno porte.
\end{abstract}

Palavras-chave: Recuperação de empresas. Recuperação judicial. Crise econômico-financeira. Princípio da preservação da empresa. Plano de recuperação. Viabilidade econômica.

\begin{abstract}
:
This paper addresses the Judicial Reorganization of Companies based on the Entrepreneurial Doctrine, consistent with the Law 11.101/2005 as well as with Brazilian jurisprudence. It presents both the judicial reorganization as one kind of reorganization of companies and the preservation of viable business principle, which has become a guideline for legal positions since collective interests take precedence over the individual interest. Before looking into the reorganization plan, its economic viability and approval, the paper covers the legal system of the judicial reorganization, which includes its legal character, assumptions, claims, requirements and means of reorganization. The feasibility of reorganization of cooperatives and rural companies as well as the reorganization of small businesses and small-sized companies is at last addressed.
\end{abstract}

Keywords: Reorganization of companies. Judicial reorganization (of companies). Financial and economic crisis. Preservation of viable business principle. Reorganization plan. Economic viability.

\footnotetext{
* Professor de Direito Empresarial da Universidade Estadual de Londrina. Doutor pela Faculdade de Direito da Universidade de São Paulo. Advogado.E-mail: contato@tarcisioteixeira.com.br
} 
Introdução

Este trabalho visa analisar o instituto da recuperação judicial de empresas à luz da Lei n. 11.101/2005 - Lei de recuperação empresas e falência - LRF. Desde já vale lembrar que tal norma disciplina a recuperação extrajudicial e judicial e a falência do empresário individual e da sociedade empresária. No decorrer do texto legal, o legislador denomina o empresário individual e a sociedade empresária simplesmente de "devedor" (LRF, art. $1^{\circ}$ ), a fim de evitar a repetição das expressões, o que também será adotado daqui por diante. Cabe também ponderar que há algumas atividades econômicas que estão expressamente excluídas deste regime concursal, como, por exemplo, as atividades intelectuais, as empresas de economia mista, etc., nos termos do art. $2^{\circ}$ da mesma norma.

A Lei n. 11.101/2005 revogou o Decreto-lei n. 7.661/1945, mantendo o instituto da falência, mas não contemplando o da concordata, em qualquer de suas modalidades. Entretanto, poder-se-ia dizer que as concordatas preventivas e suspensivas (que se processavam em juízo) foram substituídas pela recuperação judicial. A concordata basicamente era uma forma de ser obter dilação de prazo e/ou remissão parcial dos créditos quirografários.

A fim de melhor estruturar a análise, procurar-se-á promover um estudo da recuperação judicial de empresas sob o prisma doutrinário e de seu regime jurídico, bem como da jurisprudência brasileira. Vale destacar que será identificado quais são os interesses dos credores na recuperação judicial, no entanto, não será examinado em detalhes os interesses dos credores quanto à assembleia-geral de credores, ao comitê de credores, ao administrador judicial, ao gestor judicial, à recuperação extrajudicial e à falência, haja vista serem temas que demandariam um artigo, da mesma magnitude deste, para cada um deles.

\section{Recuperação de empresas}

O instituto da recuperação de empresas é relativamente novo no ordenamento jurídico brasileiro, o qual foi positivado por meio da Lei n. 11.101/2005; porém já é mais experimentado no exterior, como nos Estados Unidos, em França e em outros países, como veremos adiante.

No ordenamento jurídico brasileiro, até 2005, o que havia era a concordata, preventiva e suspensiva. Assim, pode-se afirmar que no Brasil a recuperação judicial é uma evolução da concordata, por isso é valido tecer algumas considerações acerca das espécies de concordata, a fim de melhor situarmos o instituo da recuperação judicial de empresas. O que faremos a seguir.

Antes, porém vale lembrar que a Lei n. 11.101/2005 revogou o Decreto-lei n. 7.661/1945, que tinha como princípio fundamental "tirar" do mercado o comerciante acometido de problemas financeiros ou econômicos. A norma revogada visava 
primordialmente a liquidação do patrimônio do devedor para assim promover a satisfação dos credores. Por sua vez, a Lei n. 11.101/2005 possui uma visão mais moderna, que busca recuperar a empresa que está em crise, principalmente.

Por isso, a recuperação da empresa não se esgota na simples satisfação dos credores, como a falência. É uma tentativa de solução para a crise econômica de um agente econômico, enquanto uma atividade empresarial. Isso ocorre porque a recuperação tem por objetivo principal proteger a atividade empresarial - a empresas -, não somente o empresário (empresário individual ou sociedade empresária).

Além disso, podemos completar dizendo que é uma tentativa de saneamento/ reorganização da empresa em crise, a fim de evitar o processo falimentar. ${ }^{1}$

De acordo com a Lei n. 11.101/2005, a recuperação de empresa pode ser judicial e extrajudicial (arts. $1^{\circ}, 47$ e 161), esta última que não faz parte do objeto deste estudo. A lei também prevê uma modalidade diferenciada para a recuperação da $\mathrm{ME}$ (microempresa) e da EPP (empresa de pequeno porte).

Alguns têm classificado a recuperação de empresas em três categorias: recuperação ordinária (a judicial); recuperação extraordinária (a extrajudicial); e recuperação especial (a da ME ou da EPP).

Outra classificação possível seria a que a recuperação especial fosse um sub-espécie da recuperação ordinária (judicial), haja vista que no fundo a recuperação da ME ou da EPP é uma recuperação judicial, mas revestida de algumas características menos burocráticas.

Rachel Sztajn considera que o legislador brasileiro atendeu à demanda social de se preservar as empresas, o que se faz por reorganização da atividade empresarial, mas, no entanto, a norma preferiu denominar o instituto de "recuperação". A autora afirma que "recuperar" tem o sentido de reaver, restaurar, repor em condições de operar. Quer dizer, que se possa ter condições de continuar uma atividade empresarial acometida por crise. ${ }^{2}$

\subsection{Concordata suspensiva e preventiva}

Como já apontado, a concordata basicamente era uma forma de ser obter dilação de prazo e/ou remissão parcial dos créditos quirografários. Ou seja, tinha uma natureza dilatória, remissória ou mista. Para melhor entendermos o direito concursal, é válido fazermos um apanhado geral do Decreto-lei n. 7.661/1945, em razão de sua relevância no Brasil.

1 COELHO, Fábio Ulhoa. Curso de direito comercial: direito de empresa. 8. ed. São Paulo: Saraiva, 2008, v. 3. p. 381.

2 SZTAJN, Rachel. Da recuperação judicial. In: SOUZA JUNIOR, Francisco Satiro; PITOMBO, Antônio Sérgio A. de Moraes (Coord.). Comentários à lei de recuperação de empresas e falência: Lei n. 11.101/2005. São Paulo: Revista dos Tribunais, 2005. p. 220. 
Tal decreto cuidava da falência e concordata do comerciante. O sentido da palavra "comerciante" abarcava aqueles que praticavam os atos de comércio, não se devendo esquecer que a teoria dos atos de comércio era a adotada pelo Código Comercial de 1850. Ato de comércio equivalia à compra com a intenção de revender (no mesmo sentido do art. 110-1 do Código Comercial francês), além de algumas outras atividades, como a bancária e a securitária.

O Decreto-lei n. 7.661/1945 disciplinava a concordata em duas modalidades: a suspensiva e a preventiva. Quanto à concordata suspensiva, durante o curso do processo de falência o comerciante falido podia requerer ao juiz a "suspensão" do processo por meio da concordata suspensiva (Decreto-lei n. 7.661/1945, arts. 177 e ss.).

Dessa forma, o processo de falência era suspenso, com o objetivo de que o devedor pudesse ter a chance de não ter sua atividade extinta. Para isso, precisava preencher alguns requisitos, por exemplo, oferecer o pagamento mínimo de $35 \%$ dos débitos à vista, ou 50\% a prazo em até dois anos.

Também estava previsto no Decreto-lei n. 7.661/1945, art. 156 e ss., a possibilidade de o devedor evitar a declaração judicial da falência requerendo ao juiz a concessão da concordata preventiva. A concordata preventiva era utilizada antes que algum credor do devedor requeresse em juízo a sua falência. $O$ instituto tinha, assim, a função de "prevenir" o processo de falência. Contudo, para efetivamente evitar a falência, o comerciante oferecia pagar seus credores quirografários da seguinte forma: (i) $50 \%$ dos débitos à vista; (ii) ou a prazo: 60\% em seis meses, 75\% em doze meses, $90 \%$ em dezoito meses, $100 \%$ em vinte e quatro meses.

\subsection{A crise e o princípio da preservação da empresa}

É importante considerar o fato de que a Lei n. 11.101/2005 visa, primordialmente, viabilizar o saneamento da empresa em crise, ficando a extinção restrita para casos em que a recuperação da atividade não é viável.

Diferentemente do Decreto-lei n. 7.661/1945, que tinha por objetivo principal eliminar do mercado o agente econômico sem condições de se manter e cumprir seus deveres, a nova legislação falimentar visa possibilitar a recuperação de agentes econômicos em estado de crise, mas que, no entanto, podem superá-la. Para tanto, a norma fornece condições para alcançar esse fim. Caso não seja possível a recuperação, a norma também contempla o instituto da falência como forma de liquidar a atividade empresarial, mas não é o seu escopo primordial.

Por essa razão, pode-se dizer que a nova legislação tem um aspecto duplo, qual seja, de recuperar e/ou extinguir atividades empresariais em crise. 
A crise de uma atividade econômica pode ocorrer por várias razões: má gestão; escassez de insumos; eventos da natureza, como estiagem ou excesso de chuvas; elevação ou diminuição excessiva de preços; crises econômicas mundiais ou regionais etc.

Para Fábio Ulhoa Coelho, a crise de uma empresa pode ser econômica, financeira ou patrimonial. Crise econômica ocorre quando as vendas dos produtos ou a prestação de serviços não são realizadas em quantidade suficiente à manutenção do negócio. A crise financeira acontece quando o empresário tem falta de fluxo de caixa, dinheiro ou recursos disponíveis para pagar suas prestações obrigacionais. Já a crise patrimonial se faz sentir quando o ativo do empresário é menor do que o seu passivo, logo, seus débitos superam os seus bens e direitos. ${ }^{3}$

Vale considerar que uma empresa pode ter sua crise enquadrada em mais de uma das espécies apontadas. A aplicação da Lei n. 11.101/2005, especialmente para a recuperação, se dá a qualquer destes tipos de crise, apesar de a lei utilizar-se da expressão "crise econômico-financeira".

Rachel Sztajn lembra que, uma crise financeira contínua, no que tange às entradas e às saídas de caixa, pode tornar-se causa de insolvabilidade, ou seja, acarretar uma crise relacionada à estrutura do ativo e do passivo. ${ }^{4}$

A Lei n. 11.101/2005 tem uma abordagem peculiar quanto à crise que pode atingir uma atividade empresarial, tendo por escopo primordial a tentativa de sanar a crise econômico-financeira que acomete uma empresa, fornecendo para tanto mecanismos que podem ou não ser submetidos ao Poder Judiciário, por meio da recuperação judicial e da recuperação extrajudicial, além de outras negociações que podem ser feitas livremente pelas partes. Apenas em segundo plano a norma visa extinguir a atividade empresarial que não tenha condições de sobrevida.

Isso decorre do princípio da preservação da empresa, que pode ser entendido como aquele que visa recuperar a atividade empresarial de crise, econômica, financeira ou patrimonial, a fim de possibilitar a continuidade do negócio, bem como a manutenção de empregos e interesses de terceiros, especialmente dos credores.

Este princípio é abstraído do art. 47 da Lei n. 11.101/2005, ao expressar que:

A recuperação judicial tem por objetivo viabilizar a superação da situação de crise econômico-financeira do devedor, a fim de permitir a manutenção da fonte produtora, do emprego dos trabalhadores e dos interesses dos credores,

COELHO, Fábio Ulhoa. Curso de direito comercial: direito de empresa, v. 3, p. 231/232.

SZTAJN, Rachel. Da recuperação judicial. In: SOUZA JUNIOR, Francisco Satiro; PITOMBO, Antônio Sérgio A. de Moraes (Coord.). Comentários à lei de recuperação de empresas e falência: Lei 11.101/2005. São Paulo: Revista dos Tribunais, 2005. p. 219. 
promovendo, assim, a preservação da empresa, sua função social e o estímulo à atividade econômica.

O princípio da preservação da empresa no fundo é o grande norteador da Lei n. 11.101/2005, tendo profundos reflexos para o ordenamento jurídico como um todo, uma vez que tem guiado posições na jurisprudência e na doutrina acerca da necessidade da preservação da empresa em detrimento de interesses particulares, seja de sócios, de credores, de trabalhadores, do fisco etc., conforme poderemos perceber no estudo que se segue.

À luz do dispositivo supra, pode-se perceber que o objetivo central da recuperação judicial é possibilitar que a crise da empresa seja superada. Isso, porque sendo a crise superada estar-se-á por consequência permitindo que se mantenha a fonte produtora de bens para a sociedade, os postos de trabalho e os interesses dos credores.

Por isso, diferentemente do revogado Decreto-lei n. 7.661/1945, em que os interesses dos credores eram atendidos substancialmente a partir da liquidação do patrimônio do devedor, pode-se afirmar que pelo princípio da preservação da empresa os interesses dos credores ficam subordinados a superação da crise da empresa. Ou seja, atualmente a legislação busca primordialmente a preservação da empresa.

Além disso, o princípio da preservação da empresa deve ser visto ao lado do princípio da função social da empresa (derivado da função social da propriedade), que considera o fato de a atividade empresarial ser a fonte produtora de bens para a sociedade como um todo, pela geração de empregos; pelo desenvolvimento da comunidade que está à sua volta; pela arrecadação de tributos; pelo respeito ao meio ambiente e aos consumidores; pela proteção ao direito dos acionistas minoritários etc.

Também, vale apontar que toda atividade empresarial, em maior ou menor grau, envolve risco; por isso, o ordenamento jurídico, em especial as leis empresariais, busca estimular o desenvolvimento da atividade econômica por meio de incentivos, como, por exemplo, com regras sobre a separação patrimonial e a limitação de responsabilidade. Assim, o instituto da recuperação de empresa deve ser visto como mais um incentivo ao empreendedorismo, uma vez que se pode contar com essa ferramenta em caso de uma crise afetar a atividade empresarial.

Sem dúvida, hão de aparecer aqueles que vão tentar se aproveitar do princípio da preservação da empresa a fim de obter vantagens ilícitas e imorais, como aconteceu com a revogada concordata preventiva, mas será preciso combater este tipo de postura, sob pena de a recuperação de empresas cair em total descrédito, como aconteceu com a revogada concordata. 
A propósito, Haroldo Malheiros Duclerc Verçosa alerta para o fato de que, ao se tratar de fraude, a concordata muitas vezes servia como ponto de partida para a falência, sendo altamente desvantajosa para os credores. ${ }^{5}$

\section{Recuperação judicial}

Recuperação de empresa judicial é aquela que é processada integralmente no âmbito do Poder Judiciário, por meio de uma ação judicial, com rito processual próprio, visando a solução para a crise econômica ou financeira da empresa.

Diversamente, a recuperação extrajudicial consiste na convocação de credores para contratar dilação no prazo dos pagamentos ou diminuição dos valores no âmbito privado e contratual, mas que necessitam de homologação do juízo judicial. É um procedimento "alternativo" ou "extraordinário", pois existe o procedimento da recuperação judicial, que é o ordinário. Denomina-se "extrajudicial”, pois as negociações são firmadas no âmbito privado, e não em um processo judicial, sendo apenas homologadas pelo juiz. Contudo, este trabalho visa análise tão-somente da recuperação judicial de empresas.

\subsection{Natureza jurídica, pressupostos e créditos abrangidos}

Quanto à natureza jurídica da recuperação judicial, Jorge Lobo aporta haver divergência. Os privatistas entendem ser a recuperação judicial um instituto do direito privado. Já os publicistas, do direito público. No entanto, o autor prefere situar a recuperação de empresas como instituto do direito econômico. Isso pois considera que este ramo do Direito, o direito econômico, está em uma zona intermediária entre o direito privado e o público, alinhado ao fato de que a recuperação esta pautada não necessariamente pela ideia de justiça, mas de eficácia técnica ao criar condições que propiciem às empresas em crise se reestruturarem, prevalecendo os interesses coletivos ainda que isso resulte em sacrifício parcial de credores. Assim, a recuperação de empresas teria como fundamento a ética da solidariedade, em que se visa atender aos interesses das partes envolvidas e harmonizar os direitos de cada um ao invés de estabelecer o confronto entre devedor e credores; sendo, portanto, um procedimento de sacrifício. ${ }^{6}$

Jorge Lobo, ao estudar a recuperação judicial, expressa que há pressupostos de cunho subjetivo e objetivo. O pressuposto subjetivo está relacionado com a legitimidade para requerer a recuperação judicial. Podem requerer a recuperação judicial o empresário

5 VERÇOSA, Haroldo Malheiros Duclerc. Prefácio do livro de Vera Helena de Mello Franco e Rachel Sztajn. Falência e recuperação da empresa em crise. Rio de Janeiro: Elsevier, 2008.

6 LOBO, Jorge. Da recuperação judicial. In: TOLEDO, Paulo Fernando Campos Salles de; ABRÃO, Carlos Henrique (Coord.). Comentários à Lei de recuperação de empresas e falência. 4. ed. São Paulo: Saraiva, 2010. p. 173/179. 
individual e a sociedade empresária, o que a Lei n. 11.101/2005, art. $1^{\circ}$, denomina simplesmente de devedor. ${ }^{7}$

Por sua vez, o pressuposto objetivo é o "estado de crise econômicofinanceira" do devedor, que está relacionado com o inadimplemento, iliquidez ou insolvência. Inadimplemento quer dizer o não pagamento de obrigação líquida e certa no prazo firmado. Iliquidez significa inadimplemento provisório do devedor, que não consegue cumprir as obrigações em dia, muito embora possua bens suficientes para satisfazer dívidas vencidas e vincendas. Insolvência é o inadimplemento definitivo, que se dá quando o ativo (bens e direitos) é inferior ao passivo (obrigações). ${ }^{8}$

$\mathrm{O}$ autor ainda aponta outros fatores que podem ameaçar a continuidade da empresa, como: desentendimento entre sócios ou entre estes e administradores; má administração; erros estratégicos; enfermidade do principal sócio ou administrador; falência de fornecedores ou clientes relevantes; surgimento de concorrentes com preços mais baixos; elevação dos custos operacionais; estoque excessivo; linha de produção obsoleta; entre outros.

Estão sujeitos à recuperação judicial os créditos vencidos ou vincendos na data do pedido (LRF, art. 49), desde que sejam os credores titulares de créditos: trabalhistas, acidentários, quirografários, com garantia real, com privilégio especial ou geral e subordinados. Vale destacar que, os créditos subordinados (ou subquirografários) são assim classificados por força de contrato ou de lei, como, por exemplo, dispõe o art. $58, \S 4^{\circ}$, da Lei n. 6.404/76 que a debênture que não gozar de garantia poderá conter cláusula de subordinação aos credores quirografários, preferindo apenas aos acionistas no ativo remanescente, se houver, em caso de liquidação da companhia. Bem como são subordinados os créditos de sócios e administradores, sem vínculos empregatícios, perante a empresa, como os créditos derivados de pro labore em razão do trabalho desempenhado ou de dividendos pela participação nos lucros da empresa ao tempo da decretação da falência.

No entanto, não são abrangidos pela recuperação judicial os seguintes créditos: 1) de natureza tributária (LRF, art. 57 cc. CTN, art. 187); 2) decorrentes de credores do devedor (em recuperação judicial) contra os coobrigados, fiadores e obrigados de regresso (LRF, art. 49, $\S 1^{\circ}$ ); 3) decorrentes de importâncias entregues ao devedor como adiantamento em contrato de câmbio para exportação - ACC - (LRF, art. 49, § $4^{\circ}$ cc. art. 86, II); 4) do arrendador mercantil (contrato de leasing), do proprietário fiduciário, do promitente vendedor de imóvel cujos contratos contenham cláusula de irrevogabilidade ou irretratabilidade, do proprietário em contrato de venda com reserva de domínio (LRF, art. $49, \S 3^{\circ}$ ).

\footnotetext{
$7 \quad$ Id. Ibid., p. 183/184.

$8 \quad$ Id. Ibid., p. 176/178.
} 
Isso se dá em razão da preservação do direito real sobre a propriedade do bem, que tem o alienante ou promitente em detrimento do adquirente pelo fato de havido um inadimplemento contratual deste. Assim, esses credores poderão exercer seus direitos contra o devedor a margem do processo de recuperação, podendo efetuar cobrança, execução, reintegração de posse ou busca e apreensão, a depender do caso.

Mas, vale esclarecer que o exercício destes direitos assegurados a estes credores poderá inviabilizar a recuperação judicial da empresa, especialmente se grande parte de sua dívida tiver relação com estes credores. $\mathrm{O} \S 3^{\circ}$ do art. 49 assevera que se tratando de bens de capital essenciais ao desenvolvimento da atividade empresarial eles não poderão ser retirados do estabelecimento pelo prazo de cento e oitenta dias, previsto no art. $6^{\circ}, \S 4^{\circ}$ da Lei n. 11.101/2005. Cabe ponderar que, bens de capital são os recursos utilizados para que a empresa possa desenvolver sua atividade fim, ou seja, produzir ou circular bens ou serviços, como, por exemplo, máquinas, equipamentos, tecnologia, etc.

Quanto aos possíveis efeitos que este tipo de opção legislativa pode provocar na economia por não estender a recuperação a todos os credores, vale resgatar as palavras de Armando Castelar Pinheiro e Jairo Saddi. Eles afirmam que há evidência empírica indicando que uma boa proteção aos credores leva a juros mais baixos e a um mercado de crédito mais ativo, exemplificando, que nos Estados Unidos há estudos demonstrando que a taxa de juros é mais alta nos estados norte-americanos cuja legislação é mais protetiva aos devedores. ${ }^{9}$

2.2. Suspensão da prescrição, das ações e das execuções. Sócios solidários e sócios garantidores

O deferimento da recuperação judicial ou a decretação da falência suspende o prazo prescricional e as ações e execuções judiciais contra o devedor (LRF, art. $6^{\circ}$, caput). No entanto, ações trabalhistas e as execuções fiscais não são alcançadas por esta regra, permanecendo seu trâmite nas justiças especializadas (LRF, art. $6^{\circ}, \S \S 1^{\circ}, 2^{\circ}$ e $7^{\circ}$ ).

Quanto às execuções trabalhistas e a recuperação judicial há um aparente conflito de interesses, de um lado o trabalhador individual buscando satisfazer seu crédito na justiça do trabalho (quando não estiver contemplado pelo plano de recuperação), de outro a recuperação de uma empresa que se processa em favor da manutenção da empresa, empregos, etc.

Diante disso, o Superior Tribunal de Justiça tem se manifestado no sentido que a execução trabalhista individual não pode prevalecer à recuperação da empresa. Isso

9 PINHEIRO, Armando Castelar; SADDI, Jairo. Direito, economia e mercados. Rio de Janeiro: Elsevier, 2005. p. 201. 
também vale para a falência, ou seja, as execuções pendentes na justiça do trabalho devem prosseguir no juízo universal:

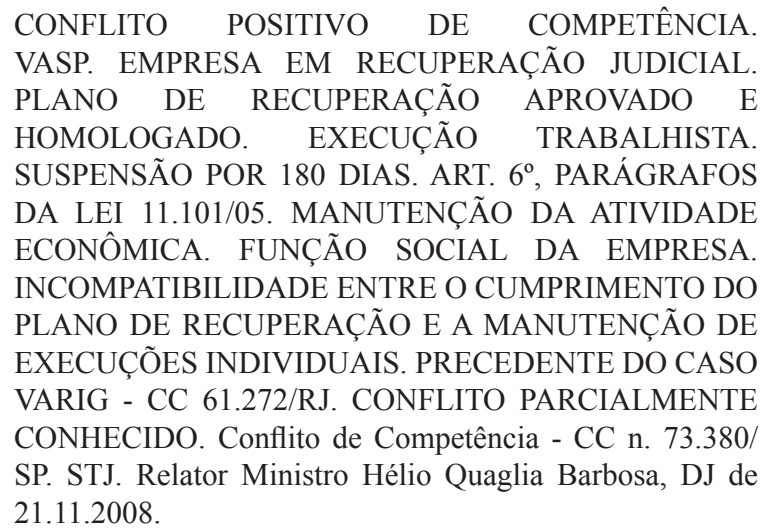

Não se pode deixar passar sem comentar o fato de que o caput do art. $6^{\circ}$ refere-se expressamente em suspensão da prescrição, não interrupção. Assim, vale resgatar a diferença entre ambas. A suspensão faz com que o prazo volte a correr pelo tempo restante. Já a interrupção tem por efeito o fato de que haverá uma recontagem do prazo, iniciando-se novamente. Manoel Justino Bezerra Filho lembra que a decadência não pode ser suspensa ou interrompida, mas que, no entanto, o referido dispositivo legal cuida apenas da prescrição. ${ }^{10}$

Além disso, na recuperação judicial, a suspensão da prescrição e das ações e execuções contra o devedor não excederão o prazo improrrogável de 180 dias, que é contado do deferimento do processamento da recuperação, restabelecendo-se, após o decurso do prazo, o direito dos credores de iniciar ou continuar suas ações e execuções, independentemente de pronunciamento judicial (LRF, art. $6^{\circ}, \S 4^{\circ}$ ). No entanto, vale ressaltar que a jurisprudência vem entendendo que este prazo não deve ser aplicado isoladamente, pois se há um plano de recuperação em curso, o credor particular deve se submeter a ele e seus respectivos prazos, tendo em vista o princípio da preservação da empresa. Nesse sentido:

Agravo de instrumento. Decisão que, em ação indenizatória, em fase de execução, determinou o prosseguimento da ação, uma vez decorrido o prazo de 180 dias, contados do deferimento da recuperação judicial e, portanto, findo o período de suspensão determinado pelo art. $6^{\circ}$ da Lei n. 11.101/05. Reforma. A decretação da falência ou o deferimento do processamento da recuperação judicial suspende o curso da prescrição e de todas as ações e

10 BEZERRA FILHO, Manoel Justino. Nova lei de recuperação e falências comentada. 3. ed. São Paulo: RT, 2005. p. 59/60. 
execuções em face do devedor, inclusive aquelas dos credores particulares do sócio solidário. O prazo disposto no parágrafo $4^{\circ}$ do artigo $6^{\circ}$ da Lei de $11.101 / 05$ não pode receber uma interpretação isolada, e dissociada do espírito reestruturador criado pela própria norma. Se há plano de recuperação em curso regular, devidamente aprovado e homologado, todos os créditos devem se submeter a ele, até mesmo porque o pagamento aos credores se fará nos termos do referido plano que foi votado em assembléia de credores, não havendo como privilegiar um credor em uma execução individual. Impossibilidade de preterição dos demais credores e quebra no planejamento financeiro da devedora. Precedentes Jurisprudenciais do Eg. Superior Tribunal de Justiça: "Deve-se interpretar o art. $6^{\circ}$ desse diploma legal de modo sistemático com seus demais preceitos, especialmente à luz do princípio da preservação da empresa, insculpido no artigo 47, que preconiza: "A recuperação judicial tem por objetivo viabilizar a superação da situação de crise econômico financeira do devedor, a fim de permitir a manutenção da fonte produtora, do emprego dos trabalhadores e dos interesses dos credores, promovendo, assim, a preservação da empresa, sua função social e o estímulo à atividade econômica". No caso, o destino do patrimônio da empresa-ré em processo de recuperação judicial não pode ser atingido por decisões prolatadas por juízo diverso daquele da Recuperação, sob pena de prejudicar o funcionamento do estabelecimento, comprometendo o sucesso de seu plano de recuperação, ainda que ultrapassado o prazo legal de suspensão constante do $\S 4^{\circ}$ do art. $6^{\circ}$, da Lei $n^{\circ} 11.101 / 05$, sob pena de violar o princípio da continuidade da empresa. (CC 79170/SP, Ministro Castro Meira, DJe 19/09/2008). Provimento do recurso para suspender a execução a qual deverá se submeter aos ditames do processo de Recuperação Judicial, de acordo com decisão do Eg. STJ acima. AGRAVO DE INSTRUMENTO 0007562-46.2009.8.19.0000. TJRJ. Décima quinta câmara cível. Relator(a) Des. HELDA LIMA MEIRELES. DJ 19/05/2009.

Um ponto muito importante que não se pode deixar passar despercebido está no caput do art. $6^{\circ}$, da Lei n. 11.101/2005, que tem a seguinte redação:

A decretação da falência ou o deferimento do processamento da recuperação judicial suspende o curso da prescrição e de todas as ações e execuções em face do devedor, inclusive aquelas dos credores particulares do sócio solidário.

A expressão final do dispositivo sócio solidário tem dado ensejo a uma grande discussão. Alguns entendem que sócio solidário é tão-somente aquele que tem a 
obrigação solidária firmada em contrato social, conforme o tipo societário adotado pela sociedade, como no caso da sociedade em nome coletivo ou comandita por ações.

Outros defendem que por sócio solidário pode ser entendida também a figura do sócio que firmou obrigação de aval em favor da sociedade devedora, pois o aval é uma garantia que implica na responsabilidade do avalista (na hipótese, o sócio) pelo inadimplemento do devedor principal (no caso, a sociedade). Neste caso, havendo o deferimento da recuperação judicial não poderia o credor cobrar a dívida do garantidoravalista, pedir sua falência, nem registrar seu nome em órgão de proteção ao crédito, pois estaria inexigível a cobrança tanto quanto à devedora principal (sociedade) quanto aos garantidores (sócios avalistas). Nesse sentido, Apelação n. 7.166.479-6 do Tribunal de Justiça de São Paulo.

Referida norma não faz menção expressa aos garantidores, em especial avalistas. Porém, esse tema deve ser visto à luz do ordenamento jurídico, como um conjunto de normas que se complementam. Neste caso é preciso haver uma integração da Lei n. 11.101/2005 com a norma disciplinadora do aval, Decreto n. 57.663/66 - Lei Uniforme -, art. 30 a 32 .

Isso, pois o instituto do aval, como visto anteriormente, é um tipo de garantia fidejussória solidária e "autônoma", em que a garantia do avalista persiste, em geral, mesmo que a obrigação principal seja nula ou extinta. Por isso, à propósito, difere da fiança que é garantia acessória e subsidiária, via de regra.

A garantia autônoma do aval está relacionada com o princípio cambial da autonomia, em que se um título representar mais de uma obrigação cada uma delas será independente em relação à outra, sendo que uma possível invalidade de uma não se estende à outra. Logo, o entendimento de que o deferimento da recuperação torna inexigível a cobrança contra os avalistas parece-nos equivocado, pois caso torne-se predominante, haverá um esvaziamento do instituto do aval como garantia, bem como muita insegurança jurídica nos negócios mercantis, o que terá por consequência o fato de os credores das sociedades empresárias passarem a exigir tamanhas garantias que provavelmente muitos negócios serão inviabilizados. Além disso, esse tema deve ser visto à luz do disposto no art. $49, \S 1^{\circ}$, da Lei n. 11.101/2005, ao estabelecer que os credores do devedor em recuperação judicial conservam seus direitos e privilégios contra os coobrigados. $\mathrm{O}$ avalista é um coobrigado.

Diante do exposto, consideramos que a suspensão da prescrição referida no caput do art. $6^{\circ}$, da Lei n. 11.101/2005, não se aplica ao sócio que prestar garantia de aval em favor da sociedade, pois o avalista pode ser cobrado, protestado etc. independentemente de a dívida principal ser exigível ou não contra o devedor principal (a sociedade em recuperação). Esta regra aplica-se somente aos sócios que tenham responsabilidade solidária em razão do tipo societário expresso no contrato social. 
Quanto à fiança, pela regra geral, por ser uma garantia subsidiária e acessória, que por sua vez extingue-se com o principal, havendo a suspensão da prescrição da dívida principal, a princípio, poderia se defender que a garantia do sócio fiador estaria suspensa, haja vista a impossibilidade de se cobrar o devedor principal. No entanto, o $\S 1^{\circ}$ art. 49, da Lei n. 11.101/2005, expressa que os credores do devedor em recuperação judicial conservam seus direitos e privilégios contra fiadores. Ou seja, o sócio fiador da sociedade, que obteve o benefício da recuperação judicial, poderá ser cobrado e/ou protestado pela dívida, pois a suspensão não opera a seu favor.

\subsection{Requisitos e meios de recuperação}

A Lei 11.101/2005, art. 49, prevê uma séria de requisitos para se poder utilizar-se da recuperação de judicial de empresas. Assim, quem pode requerer a recuperação judicial, em juízo, é o devedor - empresário individual ou sociedade empresária -, desde que atenda aos seguintes requisitos: 1) exerça regularmente a atividade empresarial por mais de dois anos; 2) não ter obtido concessão de recuperação judicial há pelo menos cinco anos; 3 ) não ter obtido concessão de recuperação especial para microempresa ou empresa de pequeno porte há pelo menos oito anos; 4) não ser falido (se foi no passado, que no presente esteja reabilitado com sentença declarando extintas suas responsabilidades); 5) não ter sido condenado por crimes concursais (crimes previstos na Lei n. 11.101/2005).

Rachel Sztajn lembra que o primeiro requisito, estabelecido pelo art. 48, espelha a regra prevista no revogado Decreto-lei n. $7.661 / 1945$, art. 158, inc. I, no que se refere ao exercício do comércio há mais de dois anos, a fim de se obter a concordata preventiva. ${ }^{11}$

Vale destacar que os requisitos previstos no art. 48 da Lei n. 11.101/2005 são cumulativos. E, quanto a exercer regularmente atividade empresarial, cabe explicitar que apenas o empresário (individual ou sociedade empresária) devidamente inscrito no Registro Público das Empresas Mercantis poderá requerer a recuperação judicial, não cabendo esse direito a quem exerça atividade empresarial de fato ou irregularmente.

O requisito de "não ser condenado por crime concursal" poderia ser visto como redundante, no entanto, não o é. Isso, pois, numa leitura precipitada, poderia se levar em conta que o condenado por este crime precisaria ser falido; mas na verdade existem pessoas que podem ser condenadas por crime concursal sem ter falido, como o administrador judicial e outros previstos no art. 179 da Lei n. 11.101/2005.

$\overline{11}$ SZTAJN, Rachel. "Da recuperação judicial”. In: SOUZA JUNIOR, Francisco Satiro; PITOMBO, Antônio Sérgio A. de Moraes (Coord.). Comentários à lei de recuperação de empresas e falência: Lei 11.101/2005. p. 222. 
Sidnei Agostinho Beneti afirma que o art. 48 estabeleceu requisitos para a concessão da recuperação judicial. No caput tem-se um requisito objetivo, que se dá quanto ao fato de a recuperação prescindir do exercício regular de atividade empresarial há mais de dois anos. Já nos incisos estão os demais requisitos que são subjetivos, conforme apontado anteriormente (não se falido, não ter obtido o benefício da recuperação há menos de cinco anos, etc.). ${ }^{12}$

Cabe lembrar que, o direito de se requerer a recuperação judicial também pode ser exercido pelo cônjuge sobrevivente, herdeiros do devedor, inventariante ou sócio remanescente (LRF, art. 48, parágrafo único).

Quanto aos meios de recuperação judicial, vale lembrar que antigamente, de acordo com o Decreto-lei n. 7.661/1945, a concordata era a única forma existente de o devedor, que não dispunha de recursos suficientes, evitar sua falência. A concordata consistia-se basicamente em: (i) um perdão parcial dos débitos; (ii) a dilação dos prazos de pagamentos; ou (iii) a combinação de ambas hipóteses.

Por sua vez, de modo diferente, a Lei n. 11.101/2005 traz várias maneiras para o devedor evitar sua falência utilizando-se da recuperação judicial (LRF, art. 50): 1) concessão de prazos e condições especiais (p. ex., descontos) para pagamento das obrigações vencidas ou vincendas; 2) transformação, cisão, fusão ou incorporação da sociedade; 3 ) trespasse ou arrendamento do estabelecimento; 4) venda parcial dos bens; 5) redução salarial, compensação de horas e redução de jornada (mediante acordo ou convenção coletiva); 6) administração compartilhada; 7) usufruto da empresa (que pode ser feito por meio da formação de uma cooperativa dos trabalhadores que irá gerir o negócio); 8) alteração do controle acionário; 9) constituição de sociedade de credores; 10) aumento de capital social; 11) emissão de valores mobiliários etc.

$\mathrm{O}$ art. 50 da Lei n. 11.101/2005, além dos meios que ele enumera, que podem ser tidos por típicos, autoriza a adoção de quaisquer outros métodos para recuperar a empresa. Seriam meios atípicos de recuperação quanto à previsão legal. Obviamente, qualquer possibilidade atípica será permitida desde que não atente à norma de ordem pública, à moral, à boa-fé e à função social do contrato. Além disso, poderá haver a combinação das possibilidades elencadas pela lei. Igualmente elas também podem ser associadas a outras não previstas pela norma.

Sidnei Agostinho Beneti, ao afirmar que a lei apenas enumera as possibilidades de forma exemplificativa e não exaustiva, aponta que a norma deixou

12 BENETI, Sidnei Agostinho. "O processo de recuperação judicial”. In: PAIVA, Luiz Fernando Valente de (Coord.). Direito falimentar e a nova lei de falências e recuperação de empresas. São Paulo: Quartier Latin, 2005. p. 230/231. 
aberta à criatividade dos empresários e dos juristas outras possibilidades de recuperação uma empresa em crise. $^{13}$

No aspecto processual, a lei se expressa no sentido de que a recuperação judicial é uma ação. Para tanto, deve-se ajuizá-la por meio de uma petição inicial do devedor, a qual deverá ser instruída com uma série de documentos e informações, conforme prevê o art. 51: 1) exposição das causas da crise econômico-financeira; 2) relação completa dos credores; 3) relação dos empregados e débitos pendentes; 4) extratos bancários atualizados; 5) certidões de cartórios de protesto; 6) relação dos bens particulares dos sócios controladores e dos administradores; 7) certidão de regularidade no Registro Público de Empresas Mercantis - Junta Comercial; 8) relação das ações judiciais em que for parte (autor e réu); 9) demonstrações contábeis dos 3 últimos exercícios; 10) demonstrações contábeis levantadas exclusivamente para instruir o pedido, compreendendo balanço patrimonial, demonstrações de resultados etc.

Quanto à necessidade de se apresentar a relação dos bens particulares dos sócios controladores e dos administradores, isso tem a finalidade de verificar se os sócios não estão enriquecendo em detrimento da empresa, ou, conforme o art. 82, para eventual ação de apuração de responsabilidade pessoal contra os sócios. Trata-se de um dispositivo bastante questionável, especialmente sob o prisma de o devedor ter de apresentar previamente o seu patrimônio para eventual penhora do credor em ação futura, contrariando a dinâmica processual ordinária.

É importante salientar que o empresário irregular, entre outras implicações, não faz jus à recuperação de empresas, haja vista ser um direito assegurado ao empresário individual e a sociedade empresaria devidamente inscrito/registrado na Junta Comercial. Ressalte-se que existem muitas sociedades que apesar de registradas na Junta Comercial estão irregulares, pois o Código Civil de 2002 estabeleceu um prazo que elas se ajustassem seus contratos sociais às disposições desta norma, o que, apesar de passados vários anos, ainda não foi realizado por muitas sociedades. Logo, estão irregulares, prejudicando o atendimento deste requisito.

Ressalta-se que as microempresas e empresas de pequeno porte poderão apresentar livros e escrituração contábil simplificados, em vez das demonstrações citadas exigidas (LRF, art. 51, $\S 2^{\circ}$ ).

Estando em ordem a documentação, o juiz deferirá o processamento da recuperação judicial e, no mesmo ato - despacho (LRF, art. 52): nomeará administrador judicial; ordenará a suspensão das ações e execuções em curso contra o devedor; e determinará a expedição de edital com: (i) resumo do pedido, (ii) relação de credores, (iii) advertência sobre os prazos para habilitações de créditos, e (iv) alerta quanto ao prazo

13 BENETI, Sidnei Agostinho. "O processo de recuperação judicial”. In: PAIVA, Luiz Fernando Valente de (Coord.). Direito falimentar e a nova lei de falências e recuperação de empresas. p. 226. 
para os credores apresentarem objeções (oposição, obstáculo, impedimento, contestação) ao plano de recuperação judicial apresentado pelo devedor.

Contudo, após o deferimento de seu processamento pelo juiz, o devedor não poderá desistir do seu pedido de recuperação judicial, a não ser que receba aprovação da assembleia-geral de credores (LRF, art. 52, $\S 4^{\circ}$ ).

2.4. O plano de recuperação e sua viabilidade econômica

O plano de recuperação judicial consiste na estratégia traçada para se recuperar a empresa em crise. Esta estratégia pode ser traçada pelo próprio empresário, advogado ou profissional contratado para tal fim. No mercado existem empresas especializadas em elaborar estratégias para a recuperação empresarial, as quais contam com profissionais de diversas áreas: contabilidade, economia, administração de empresas, direito etc.

A partir da publicação da decisão que deferiu o processamento da recuperação judicial, o devedor terá o prazo, improrrogável, de sessenta dias para apresentar em juízo o plano de recuperação judicial (LRF, art. 53). No Brasil, apenas o devedor tem a prerrogativa de apresentar o plano de recuperação judicial. Caso o devedor não o apresente no prazo, a recuperação judicial será convertida em falência (LRF, art. 53 cc. art. 73, II). Nesse sentido:

\section{AGRAVO. RECUPERAÇÃO JUDICIAL CONVOLADA EM FALÊNCIA EM RAZÃO DA NÃO APRESENTAÇÃO DO PLANO NO PRAZO DE 60 DIAS. DESÍDIA DA EMPRESA DEVEDORA. PRAZO IMPRORROGÁVEL. SENTENÇA DE QUEBRA MANTIDA. AGRAVO IMPROVIDO. AI 990101050528. TJSP. Câmara Reservada à Falência e Recuperação. Relator Pereira Calças. DJ $16 / 04 / 2010$}

Dependendo da complexidade da atividade empresarial, elaborar um plano de recuperação em sessenta ias pode ser algo complicado e difícil. Por isso, na prática, muitas vezes se começar a trabalhar na elaboração do plano, e até mesmo na negociação com credores, antes de o juiz se pronunciar ou mesmo antes de se ajuizar a recuperação.

Este plano de recuperação pode envolver qualquer possibilidade prevista no art. 50 da Lei n. 11.101/2005 (concessão de prazos ou descontos; transformação, cisão, fusão ou incorporação da sociedade; trespasse ou arrendamento do estabelecimento; etc.), podendo haver a combinação de mais de uma delas, sem prejuízo da adoção de alternativas não previstas pela referida norma, mas por ela autorizada no mesmo dispositivo legal.

O plano de recuperação judicial, à luz do art. 53, I a III, da Lei n. 11.101/2005, deve conter os seguintes requisitos: 1) meios detalhados de recuperação a ser utilizados; 2) laudo econômico-financeiro e de avaliação dos bens e ativos do devedor, subscrito 
por profissional legalmente habilitado ou empresa especializada (visando uma avaliação fidedigna); 3 ) demonstração de sua viabilidade econômica.

Por viabilidade econômica entenda-se a chance que a empresa tem de se recuperar, ou seja, ela deverá apresentar condições mínimas para ser saneada e assim poder obter o favor legal da recuperação judicial. As condições mínimas podem consistir, por exemplo, em ter um ativo imobilizado que em parte será alienado a fim de pagar os débitos; no fato de sua marca (e/ou seus produtos e serviços) ter boa aceitação no mercado; etc.

Pelo dispositivo legal, fica claro que a norma concursal não visa socorrer empresas irrecuperáveis do ponto de vista econômico. A estas restará a possibilidade de tentar concretizar acordos com seus credores, podendo ou não ser homologáveis por meio da recuperação extrajudicial; receber aportes de recursos pelos seus atuais e/ou eventuais novos sócios; ou a decretação da falência.

A demonstração da possibilidade de se recuperar do ponto de vista econômico deve ser convincente, sob pena de não aprovação do plano pelos credores em assembleia. Essa credibilidade poderá ser maior quando houver um relatório assinado por especialista em recuperação e, se possível, no segmento em que a empresa atua.

\subsubsection{Aprovação do plano, cram down e novação}

Antes de tratarmos da aprovação do plano de recuperação judicial de empresas, vale tecer algumas considerações acerca da possibilidade do plano sofrer objeção, rejeição ou modificação.

Uma vez apresentado o plano de recuperação judicial pelo devedor, caberá ao juiz ordenar a publicação do plano fixando o prazo para eventuais objeções (LRF, art. 53, parágrafo único). Qualquer credor poderá apresentar objeção ao plano no prazo de trinta dias (LRF, art. 55). Havendo objeção, o juiz convocará assembleia-geral de credores para deliberar sobre o plano, no prazo máximo de cento e cinquenta dias a partir da decisão que deferiu o processamento da recuperação (LRF, art. 56, caput e $\S 1^{\circ}$ ).

O plano de recuperação poderá ser modificado pela assembleia-geral desde que exista concordância do devedor ( $\mathrm{LRF}$, art. 56, § $3^{\circ}$ ). A concordância do devedor é necessária, pois, além de ser titular dos bens, é ele quem está na administração e, portanto, quem melhor conhece a atividade, além de o negócio ser dele. Se por acaso a assembleiageral de credores rejeitar o plano de recuperação, o juiz decretará a falência do devedor (LRF, art. 56, $\S 4^{\circ}$ cc. art. 73, III). Acerca da soberania ou não assembleia-geral de credores em suas deliberações, em especial na aprovação do plano, pode o juiz se sobrepor às suas decisões, notadamente nos casos de comprovada fraude e violação do ordenamento jurídico quanto às normas de ordem pública, como o princípio da par conditio creditorum. Sobre o tema: 


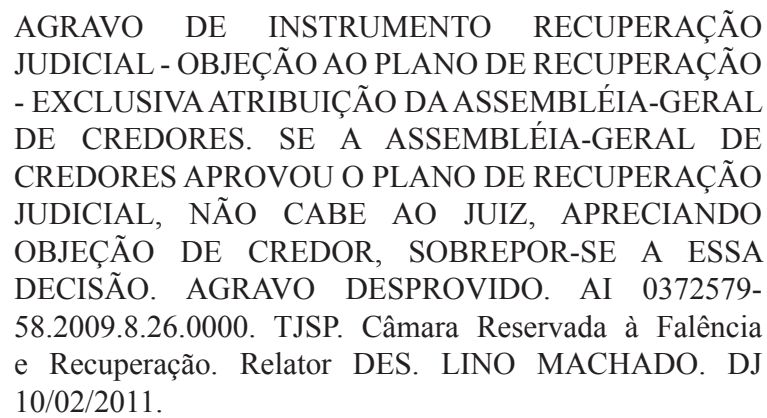

Agravo. Recuperação Judicial. Plano aprovado pela assembleia-geral de credores. Plano que prevê o pagamento do passivo em 18 anos, calculando-se os pagamentos em percentuais $(2,3 \%, 2,5 \%$ e $3 \%)$ incidentes sobre a receita líquida da empresa, iniciando-se os pagamentos a partir do $3^{\circ}$ ano contado da aprovação. Previsão de pagamento por cabeça até o $6^{\circ}$ ano, acarretando pagamento antecipado dos menores credores, instituindo conflitos de interesses entre os credores da mesma classe. Pagamentos sem incidência de juros. Previsão de remissão ou anistia dos saldos devedores caso, após os pagamentos do $18^{\circ}$ ano, não haja recebimento integral. Proposta que viola os princípios gerais do direito, os princípios constitucionais da isonomia, da legalidade, da propriedade, da proporcionalidade e da razoabilidade, em especial o princípio da "par conditio creditorum" e normas de ordem pública. Previsão que permite a manipulação do resultado das deliberações assembleares. Falta de discriminação dos valores de cada parcela a ser paga que impede a aferição do cumprimento do plano e sua execução específica, haja vista a falta de liquidez e certeza do "quantum" a ser pago. Ilegalidade da cláusula que estabelece o pagamento dos credores quirografários e com garantia real após o decurso do prazo bienal da supervisão judicial (art. 61, 'caput', da Lei n. 11.101/2005). Invalidade (nulidade) da deliberação da assembleia-geral de credores declarada de ofício, com determinação de apresentação de outro plano, no prazo de 30 dias, a ser elaborado em consonância com a Constituição Federal e Lei n. 11.101/2005, a ser submetido à assembleia-geral de credores em 60 dias, sob pena de decreto de falência. AI 013636229.2011.8.26.0000. TJSP. Câmara Reservada à Falência e Recuperação. Relator DES. PEREIRA CALÇAS. DJ 29/02/2012.

A aprovação do plano de recuperação judicial pelos credores pode-se dar de forma tácita ou expressa. Tática quando o devedor apresenta o plano e nenhuma objeção é realizada pelos credores. Já a expressa se dá quando o plano é submetido à aprovação da assembleia-geral de credores.

Luiz Fernando Valente de Paiva pondera que, a Lei n. 11.101/2005 confere aos credores o direito de aceitar ou não o plano de pagamento apresentado pelo devedor, diversamente do que ocorria na norma anterior, em que na concordata suspensiva o 
devedor de forma quase que absoluta impunha as condições de pagamento aos credores quirografários. ${ }^{14}$

Quanto ao papel dos credores na aprovação do plano feita por meio da assembleia-geral, essa aprovação prescinde do cumprimento das formalidades exigidas pela lei, como a votação e a aprovação da proposta em cada classe de credores nos termos dos artigos 41 e 45. Pela regra geral, conforme determina o art. 45, caput, todas as classes de credores referidas pelo art. 41 deverão aprovar a proposta do plano, haja vista que, se uma delas não o fizer o plano não poderá seguir adiante, inviabilizando a recuperação da empresa e acarretando a sua decretação de falência.

No entanto, o $\S 1^{\circ}$ do art. 58 autoriza o juiz a conceder a recuperação judicial com base em plano que não obteve aprovação nos termos do art. 45. Para tanto, é necessário que na assembleia-geral que deliberou acerca do plano tenha-se obtido, de forma cumulativa: (i) o voto favorável de credores que representem mais da metade do valor de todos os créditos presentes à assembléia, independentemente de classes; (ii) a aprovação de duas das classes de credores nos termos do art. 45 ou, caso haja somente duas classes com credores votantes, a aprovação de pelo menos uma delas; (iii) na classe que o houver rejeitado, o voto favorável de mais de um terço dos credores, computados na forma dos $\S \S 1^{\circ}$ e $2^{\circ}$ do art. 45.

Nos Estados Unidos denomina-se como cram down essa concessão da recuperação judicial pelo juiz, mesmo não tendo havido a devida aprovação do plano pela assembleia-geral de credores.

Assim, nas hipóteses de aprovação do plano pela assembleia-geral de credores, de não ter havido objeção ou de cram down o juiz proferirá decisão concedendo a recuperação judicial (LRF, art. 58, caput e $\S 2^{\circ}$ ). Contra essa decisão, caberá agravo, que poderá ser interposto por qualquer credor ou Ministério Público (LRF, art. 59, § $2^{\circ}$ ).

Com a homologação do plano de recuperação judicial haverá a novação dos créditos anteriores ao pedido, obrigando assim o devedor e todos os credores a ele sujeitos (LRF, art. 59, caput). O instituto da novação está disciplinado no Código Civil, arts. 360 a 367, aplicáveis ao caso, portanto, no que for compatível. Basicamente, para fins de recuperação judicial, a novação pode ser vista como uma obrigação nova para extinguir uma anterior; ou o fato de um novo devedor suceder ao anterior.

Vale ter em conta que a decisão judicial que conceder a recuperação judicial constituirá título executivo judicial, de acordo com o Código de Processo Civil, art. 584, inc. III (LRF, art. 59, $\S 1^{\circ}$ ). Isto quer dizer que, sendo título executivo judicial, em caso de

14 PAIVA, Luiz Fernando Valente de. Apresentação do plano de recuperação pelo devedor e a atuação dos credores. Revista do Advogado, São Paulo, n. 83. São Paulo: AASP, 2005. p. 74. 
inadimplemento, permite ao seu credor a execução direta do crédito sem a necessidade de processo de conhecimento.

Diante do exposto, havendo a novação das obrigações, pelo fato de uma obrigação nova suceder a anterior, os efeitos da antiga obrigação são extintos, como, por exemplo, o cadastro do nome do devedor junto aos órgãos de proteção ao crédito. Até porque se o devedor não cumprir o plano, contra ele os credores terão seus créditos e garantias reconstituídos, além de um título executivo judicial, sem dizer da possibilidade da convolação da recuperação em falência.

Por último, nos termos do art. 60, caput, se o plano de recuperação judicial aprovado envolver alienação judicial de filiais ou de unidades produtivas isoladas do devedor, o juiz ordenará a sua realização por leilão, propostas fechadas ou pregão (que consiste na mistura de leilão e propostas fechadas).

Muito importante foi o fato de lei sob comento deixa claro que o objeto da alienação estará livre de qualquer ônus e não haverá sucessão do arrematante nas obrigações do devedor, inclusive as de natureza tributária (LRF, art. 60, parágrafo único). Ou seja, com essa regra, os bens adquiridos de uma empresa em recuperação judicial estarão livres dos débitos anteriores que foram contraídos pelo devedor.

Para a concessão da recuperação judicial, o art. 57 da Lei n. 11.101/2005 expressa a necessidade de apresentação pelo devedor de certidões negativas de débitos tributários, nos termos do art. 151 do CTN. A lei prevê que as Fazendas (federal, estaduais e municipais) poderão deferir parcelamento dos débitos (LRF, art. 68), o que possibilita ao devedor obter uma certidão positiva com efeitos negativos. A certidão é positiva porque consta o débito, mas com efeitos negativos porque o débito será pago parceladamente.

Todavia, acontece que, quando uma empresa atinge um estado de crise, na maioria das vezes, ela há tempos não vem cumprindo com os pagamentos. E, em geral, o Fisco é o primeiro que ela deixou de pagar, muitas vezes não conseguindo atender as exigências do órgão para a efetivação de um parcelamento dos tributos.

Logo, tal dispositivo de certa forma é um obstáculo prático ao instituto da recuperação judicial de empresa, pois quase sempre os créditos tributários são os mais altos e, ao ficar de fora do plano, muitas vezes poderá inviabilizar a recuperação da empresa. Isso é tão verdade que o número de empresas que conseguiriam obter o benefício da recuperação judicial, com tal exigência, seria ainda menor do que já é. No entanto, a doutrina e a jurisprudência vem flexibilizando a exigência da lei quanto às certidões negativas, entendendo que tal determinação contraria o próprio objeto da lei e o princípio da preservação da empresa, ou seja, é um obstáculo à recuperação da empresa, manutenção dos empregos, interesses dos credores etc. A esse respeito:

AGRAVO DE INSTRUMENTO. RECUPERAÇÃO JUDICIAL Pretensão da União à exigência de apresentação de certidões negativas de débitos fiscais. 
Impropriedade Reiteração de decisões colegiadas nesse sentido. Exegese do art. 57 em confronto com o art. 47, ambos da Lei n. 11.101/2005. Recurso não provido. AI 1985973220118260000. TJSP. Câmara Reservada à Falência e Recuperação. Relator: Des. Ricardo Negrão. DJ 24/01/2012.

É importante esclarecer que o plano não poderá prever prazo superior a um ano para pagamento dos créditos trabalhistas e acidentários, vencidos até a data do pedido de recuperação judicial (LRF, art. 54, caput). O plano também não poderá ter prazo superior a trinta dias para pagamento dos salários vencidos nos três meses anteriores ao pedido, até o limite de cinco salários mínimos por trabalhador (LRF, art. 54, parágrafo único). Esse limite de até cinco salários mínimos, que pode ser pouco a depender do padrão da pessoa, tem caráter alimentar; ou seja, seria o mínimo necessário para a sobrevivência digna do trabalhador.

Esta regra pode ser exemplificada da seguinte forma (mas para facilitar vamos considerar o valor do salário mínimo como sendo de R\$ 500): um trabalhador que ganhe mensalmente $\mathrm{R} \$ 4$ mil, em três meses teria direito a receber $\mathrm{R} \$ 12 \mathrm{mil}$; porém receberá, nestes primeiros 30 dias, $\mathrm{R} \$ 2.500$ (correspondente ao limite de cinco salários mínimos). Já em outra simulação, um trabalhador que ganhe mensalmente $\mathrm{R} \$ 700$ teria direito a receber $\mathrm{R} \$ 2.100$, sendo este o valor que efetivamente deverá receber, porque não ultrapassa os cinco salários mínimos.

Além disso, a partir da decisão que conceder a recuperação judicial, o devedor permanecerá em recuperação judicial até que se cumpram as obrigações previstas no plano que vencerem em até dois anos, a partir dessa decisão que concedeu a recuperação (LRF, art. 61, caput). Esse é o denominado prazo de supervisão judicial da recuperação. Em outras palavras, o plano pode ter obrigações com vencimentos superiores há dois anos, mas a recuperação judicial durará até dois anos ${ }^{15}$.

Durante esse período de dois anos, o descumprimento de qualquer obrigação prevista no plano acarretará a convolação da recuperação em falência. Neste caso, os credores terão reconstituídos seus direitos e garantias conforme contratadas originalmente, devendo ser deduzidos os valores eventualmente pagos e ressalvados os atos praticados de forma válida durante a recuperação judicial (LRF, art. $61, \S \S 1^{\circ}$ e $2^{\circ}$ cc. art. 73, IV).

Após os dois anos, caso o devedor descumpra alguma obrigação prevista no plano - em especial as de vencimento posterior a dois anos - qualquer credor poderá requerer a falência ou a execução específica, uma vez que trata-se de título executivo a decisão que concedeu a recuperação (LRF, art. 62 cc. art. 94).

15 No mesmo sentido, BEZERRA FILHO, Manoel Justino. Nova lei de recuperação e falências comentada. p. $172 / 173$. 
Nos termos do art. 73 da Lei n. 11.101/2005, no que se refere à convolação da recuperação judicial em falência, o juiz, no curso do processo de recuperação, decretará a falência do devedor quando: 1) não for apresentado o plano de recuperação no prazo de sessenta dias (LRF, art. 73, II cc. art. 53); 2) a assembleia-geral de credores rejeitar o plano de recuperação, e não for o caso de cram down (LRF, art. 73, III cc. art. 56, § $4^{\circ}$ ); 3 ) houver o descumprimento de qualquer obrigação prevista no plano de recuperação, durante o período de dois anos (LRF, art. 73, IV, cc. art. 61, § $1^{\circ}$ ).

As regras anteriormente citadas não impedem a decretação da falência por inadimplemento de obrigação não sujeita à recuperação judicial (LRF, art. 73, parágrafo único). Em havendo a convolação em falência, os atos praticados (p. ex., vendas) durante a recuperação judicial serão presumidos válidos, desde que realizados conforme a lei (LRF, art. 74).

Como benefício aos credores que acreditaram na recuperação da empresa, que mais tarde restou infrutífera, havendo a convolação da recuperação em falência, os créditos decorrentes de obrigações contraídas pelo devedor durante a recuperação judicial, inclusive aqueles relativos a despesas com fornecedores de bens ou serviços e contratos de mútuo, serão considerados extraconcursais, devendo ser respeitada, no que couber, a ordem estabelecida no art. 83 da Lei n. 11.101/2005. No mesmo sentido, os créditos quirografários sujeitos à recuperação judicial pertencentes a fornecedores de bens ou serviços que continuaram a provê-los normalmente após o pedido de recuperação judicial terão privilégio geral de recebimento em caso de decretação de falência, no limite do valor dos bens ou serviços fornecidos durante o período da recuperação (LRF, art. 67).

Essas duas regras de reclassificação de direitos creditórios se dão pelo fato de que, os credores assumiram riscos consideráveis ao colaborarem na tentativa de auxiliar na recuperação da empresa devedora, sendo que tal atitude favoreceria aos demais credores caso a recuperação judicial prospera-se. ${ }^{16}$

Vale destacar que, conforme dispõe o art. 69 da Lei n. 11.101/2005, em todos os atos, contratos e documentos firmados pelo devedor e sujeitos à recuperação judicial, deverão ser acrescidos, após o nome empresarial, a expressão "em Recuperação Judicial". O juiz também determinará à Junta Comercial a correspondente anotação da recuperação judicial. Isso oferece publicidade ao estado da empresa, possibilitando aos que com ela forem negociar tenham como saber, por meio de consulta realizada no registro de empresas em favor dos interesses de eventuais credores que poderão vir a estabelecer relações jurídicas com o devedor.

16 COELHO, Fábio Ulhoa. Comentários à lei de falências e de recuperação de empresas. 8. ed. São Paulo: Saraiva, 2011. p. 261. 


\subsection{Manutenção da gestão do negócio}

Ressalta-se que, durante o procedimento de recuperação judicial, o devedor ou seus dirigentes (administradores) são mantidos na gestão da atividade empresarial, sob a fiscalização do comitê de credores e do administrador judicial, nos termos do art. 64. De modo diferente, na falência, o devedor é afastado da gestão empresarial. Essa regra pela manutenção da gestão pode ser vista com algo que interessa aos credores, pois teoricamente ninguém melhor que o devedor conhece o negócio.

Vale destacar que, na recuperação judicial de empresas, excepcionalmente, o devedor ou seus administradores poderão ser afastados da gestão da empresa. Neste caso, o juiz destituirá o administrador, que será substituído na forma prevista no ato constitutivo (contrato social ou estatuto) do devedor ou no plano de recuperação judicial (LRF, art. 64, parágrafo único).

$\mathrm{O}$ art. 64 da Lei n. 11.101/2005 enumera as hipóteses em que o devedor ou seus administradores poderão ser afastados da direção do negócio: 1) se o seu afastamento estiver previsto no plano de recuperação judicial; 2) se houver sido condenado em sentença penal transitada em julgado por crime cometido em recuperação judicial ou falência anteriores ou por crime contra o patrimônio, a economia popular ou a ordem econômica previstos na legislação vigente; 3) se houver indícios veementes de ter cometido crime previsto na Lei n. 11.101/2005; 4) se tiver agido com dolo, simulação ou fraude contra os interesses de seus credores; 5) se negar-se a prestar informações solicitadas pelo administrador judicial ou pelos membros do comitê de credores; 6) se houver: a) efetuado gastos pessoais manifestamente excessivos em relação a sua situação patrimonial; b) efetuado despesas injustificáveis por sua natureza ou vulto, em relação ao capital ou gênero do negócio, ao movimento das operações e a outras circunstâncias análogas; c) descapitalizado injustificadamente a empresa ou realizar operações prejudiciais ao seu funcionamento regular; d) simulado ou omitido créditos ao apresentar a relação de que trata o inciso III do caput do art. 51 da Lei n. 11.101/2005, sem relevante razão de direito ou amparo de decisão judicial.

Uma vez ocorrido o afastamento do devedor, o juiz convocará a assembleiageral de credores para a escolha do nome de um gestor. Trata-se do gestor judicial, cuja atribuição é assumir a administração das atividades do devedor no processo de recuperação judicial. A este gestor judicial são aplicáveis, no que couber, todas as normas sobre deveres, impedimentos e remuneração do administrador judicial, à luz do art. $21 \mathrm{e}$ ss. da Lei n. 11.101/2005 (LRF, art. 65, caput). Enquanto a assembleia-geral não deliberar sobre a escolha do gestor judicial, caberá ao administrador judicial exercerá as funções dele (LRF, art. 65, $\S 1^{\circ}$ ). 
2.6. Empresas rurais e cooperativas

As pessoas que desenvolvem atividades rurais somente estarão sujeitas ao regime da legislação de falência e recuperação se o agricultor optar por efetuar sua inscrição no Registro Público de Empresas Mercantis, à luz do art. 971 do Código Civil, o que o torna equiparado a empresário, ou melhor, um empresário rural. Sobre esse assunto:

RECUPERAÇÃO JUDICIAL. AÇÃO AJUIZADA
POR PRODUTORES RURAIS QUE NÃO ESTÃO
REGISTRADOS NA JUNTA COMERCIAL. "O
EMPRESÁRIO RURAL SERÁ TRATADO COMO
EMPRESÁRIO SE ASSIM O QUISER, ISTO É, SE SE
INSCREVER NO REGISTRO DAS EMPRESAS, CASO
EM QUE SERÁ CONSIDERADO UM EMPRESÁRIO,
IGUAL AOS OUTROS". “A OPÇÃO PELO REGISTRO
NA JUNTA COMERCIAL PODERÁ SE JUSTIFICAR
PARA QUE, DESFRUANDO DA POSIÇÃO JURÍDICA
DE EMPRESÁRIO, O EMPRESÁRIO RURAL POSSA SE
VALER DAS FIGURAS DA RECUPERAÇÃO JUDICIAL
E DA RECUPERAÇÃO EXTRAJUDICIAL, QUE SE
APRESENTAM COMO EFICIENTES MEIOS DE
VIABILIZARAREESTRUTURAÇÃO PRESERVAÇÃO
DA ATIVIDADE EMPRESARIAL, INSTRUMENTOS
BEM MAIS ABRANGENTES E EFICAZES DO QUE
AQUELE POSTO À DISPOSIÇÃO DO DEVEDOR CIVIL
(CONCORDATA CIVIL - CÓDIGO DE PROCESSO
CIVIL,ARTIGO 783)”. SÓ A PARTIR DA OPÇÃO
PELO REGISTRO, ESTARÁ O EMPRESÁRIO RURAL
SUJEITO INTEGRALMENTE AO REGIME APLICADO
AO EMPRESÁRIO COMUM. SENTENÇA MANTIDA.
APELAÇÃO NÃO PROVIDA. AC 994092930317. TJSP.
Câmara Reservada à Falência e Recuperação. Relator
Romeu Ricupero. DJ 16/04/2010.

Especificamente acerca da aplicação da Lei n. 11.101/2005 aos empresários rurais, isso se dará de acordo com a opção em inscrever-se ou não no Registro Público de Empresas Mercantis, conforme facultado pelos arts. 971 e 984 do Código Civil. Ao efetuar a inscrição aquele que desenvolve atividade rural será equiparado á empresário para todos os efeitos legais, logo, submeter-se-á a legislação de recuperação de empresas e falência. Segue a ementa de uma decisão do Tribunal de Justiça do Estado de São Paulo a esse respeito:

Agravo de Instrumento Recuperação Judicial - Produtores rurais - Inexistência de prévia inscrição no Registro Público de Empresas Mercantis - Impossibilidade de equiparação a empresário. Produtor rural não pode beneficiar-se nem ser prejudicado pela disciplina da recuperação judicial e das falências se não estiver inscrito no Registro Público 
de Empresas Mercantis. Tampouco pode beneficiarse da recuperação judicial em relação a operações realizadas antes de inscrever-se naquele registro, pois sua equiparação a empresário só ocorre com a referida inscrição - Todo e qualquer titular de crédito sujeito aos efeitos da recuperação judicial tem legitimidade para contraminutar agravo de instrumento interposto pela recuperando. Agravo desprovido. TJSP. Agravo de Instrumento - Ag 9031524-47.2009.8.26.0000, Relator Des. Lino Machado, Julgamento: 06/07/2010.

Paulo Fernando Campos Salles de Toledo afirma que, embora a atividade rural não seja considerada empresária por estar ligada as ciclos da natureza, diferenciandose assim fundamentalmente da organização da atividade econômica pelo empresário, por um ato de vontade o produtor rural pode equiparar-se aos empresários em geral ao efetuar seu registro na Junta Comercial. O autor aponta que a norma tem sentido ao reconhecer a realidade, pois permite, por exemplo, que uma agroindústria de porte tenha acesso à recuperação de empresas; mas, no entanto, seria irreal expor à falência um pequeno ruralista que explore com esforço próprio e de alguns familiares uma propriedade rural. ${ }^{17}$

Waldo Fazzio Júnior ao referir-se à possibilidade de o ruralista equipararse ao empresário, logo, submetido à Lei n. 11.101/2005, afirma que tal norma não faz distinção entre grande e pequeno empresário rural, não sendo essa a solução mais justa, pois há produtores que exploram a propriedade rural tão-somente para fins de subsistência familiar, diferentemente dos empreendimentos objetivados pela lei de recuperação de empresas e falência. ${ }^{18}$

Contudo, se houver inscrição no Registro Público das Empresas Mercantis, aquele que desenvolve atividade rural (individualmente ou por sociedade) se submete ao regime jurídico da Lei n. 11.101/2005 quanto à falência e recuperação de empresas. Até porque o art. $2^{\circ}$ desta norma ao excluir as atividades não ela não o faz com relação à atividade rural.

Quanto às cooperativas, a Lei n. 11.101/2005, art. 2º exclui expressamente a cooperativa de crédito de seu regime jurídico para fins de recuperação de empresas e falência. Por sua vez, a Lei n. 5.764/71 (lei da cooperativa), art. $4^{\circ}$, caput, afirma que a cooperativa é uma sociedade de pessoas, de natureza civil, não sujeita à falência, devendo sua dissolução e liquidação extrajudicial ser realizadas conforme os arts. 63 a 78

17 TOLEDO, Paulo Fernando Campos Salles de. Disposições preliminares. In: TOLEDO, Paulo Fernando Campos Salles de; ABRÃO, Carlos Henrique (Coord.). Comentários à Lei de recuperação de empresas e falência. 4. ed. São Paulo: Saraiva, 2010. p. 52.

18 FAZZIO JÚNIOR, Waldo. Lei de falência e recuperação de empresas. 4. ed. São Paulo: Atlas, 2008. p. 32. 
da mesma lei. E, complementando, o Código Civil, art. 982, parágrafo único, prevê que independentemente do seu objeto social, a cooperativa é uma sociedade simples.

Surge então um conflito aparente de normas, pois, de acordo com os arts. 998, caput, e 1.150 do Código Civil, a sociedade simples está vinculada ao Registro Civil das Pessoas Jurídicas. No entanto, apesar de a cooperativa ser considerada por lei sociedade simples, o art. 18 da Lei n. 5.764/71 determina que ela deva ser registrada no Registro Público das Empresas Mercantis (Junta Comercial), órgão encarregado do registro da sociedade empresária e da inscrição do empresário individual.

Feito esse preâmbulo, e não se questionando as cooperativas de crédito, pois estas não estão mesmo sujeitas à Lei n. 11.101/2005, por força expressa do seu art. $2^{\circ}$, a questão é saber se as cooperativas em geral (exceto as de crédito) podem ou não se submeterem a norma falimentar e recuperacional.

Quanto ao instituto da recuperação de empresas há um vácuo legislativo, o art. $2^{\circ}$ da Lei n. 11.101/2005 exclui tão-somente as cooperativas de crédito não as demais cooperativas. Já a Lei 5.764/71, art. $4^{\circ}$, caput, expressa que as cooperativas não se submetem a falência, não mencionando à recuperação de empresas (até porque esta lei foi editada em 1971 e a criação da recuperação de empresas ocorreu em 2005).

A propósito, já há decisões no Poder Judiciário autorizando a recuperação de cooperativas em razão do princípio da preservação da empresa, como, por exemplo, em Minas Gerais, Comarca de Alpinópolis, Processo n. 0009255-05-2011, que em foi deferida à recuperação judicial a uma cooperativa rural. Tem-se justificado a aplicação da recuperação de empresas à cooperativa, quando esta estiver organizada como empresa, ou seja, desenvolvedora de atividade econômica organizada com profissionalidade, visando a produção ou a circulação de bens ou de serviços. A seguir, um trecho da referida decisão do juízo de Alpinópolis:

(...) Assim, ao invocar a Lei $11.101 / 2005$, ainda que somente como referência analógica, em conduzir o processamento dos atos através da ordem delineada naquela norma, salientando que através de seu artigo $2^{\circ}$, que veda aplicabilidade desta norma através de um rol exaustivo, onde figura expressamente as "Cooperativas de Crédito", não relacionando, porém, as cooperativas agropecuárias ou agroindustriais. Entende-se assim que o legislador, ao editar a referida Lei, quis diferenciar as cooperativas de crédito das demais, vedando aplicação somente a elas, inexistindo impedimento de aplicabilidade da Recuperação Judicial às cooperativas agropecuárias. Portanto, entendo perfeitamente adequado juridicamente o pedido da parte autora, quanto a sua regularidade e adequação, adotando, assim, a aplicabilidade da Lei 11.101/05, bem como por analogia adotar as regras para acolher o pedido prefacial da recuperação judicial, comungando, pois, de igual identidade 
de entendimento com o nobre colega que decidiu situação semelhante no Estado do Rio Grande do Sul, na forma descrita às fls. 23 , no processo 11000045060 , que deferiu à COCEAGRO a recuperação judicial, como medida judicial plausível e coerente à situação da aludida cooperativa. (...)

Quanto à falência, o tema ganha outro contorno, pois mesmo a cooperativa não sendo excluída expressamente pelo art. $2^{\circ}$ da Lei n. 11.101/2005, ela está excluída por força da norma que a disciplina, ou seja, art. $4^{\circ}$ da Lei n. 5.764/71. Por isso pode-se entender que à cooperativa poderia ser concedida recuperação de empresas. No entanto, não poderá ela submeter-se à falência, mas sim a liquidação extrajudicial prevista na lei da cooperativa.

Emanuelle Urbano Maffioletti afirma que as cooperativas são consideradas empresas em muitos países. No Brasil apesar de terem um regime jurídico próprio, elas se organizam como empresas, atendendo a todos os requisitos da teoria da empresa, ou seja, exercem atividade econômica de forma profissional e concorrem com as demais empresas. Para o consumidor não há relevância em saber se o produto que ele está adquirindo deriva de uma cooperativa ou de outro tipo de empresa. O que a lei da cooperativa particulariza é a relação interna entre os sócios que são cooperados. Mas, por serem consideradas sociedade simples em razão da opção legislativa, as cooperativas ficam excluídas da lei de falência e recuperação de empresa, havendo, portanto, a necessidade um ajuste no ordenamento jurídico para que possam assim se submeter ao regime da norma falimentar e recuperacional. ${ }^{19}$

Paulo Fernando Campos Salles de Toledo afirma que as cooperativas são consideradas sociedades simples e não empresárias, logo, não estão abrangidas pela disciplina da Lei de Recuperação de Empresas e de Falência. A propósito, o autor aponta uma decisão da Câmara Especial de Falências e Recuperações Judiciais do Tribunal de Justiça de São Paulo que apreciou um agravo de instrumento que visava combater decisão judicial que deferiu a citação em um processo de falência contra uma cooperativa. O tribunal deu provimento ao agravo, ao considerar que a cooperativa não está submetida à falência por ser sociedade simples (AI 429.472.4/6-00, j. 22-2-2006, v.u., Relator Desembargador Pereira Calças). ${ }^{20}$ No entanto, em conversa informal, o autor se manifestou no sentido de aceitar a possibilidade de recuperação judicial para cooperativas, mas desde que feita alteração legislativa.

19 MAFFIOLETTI, Emanuelle Urbano. O direito concursal das sociedades cooperativas e a lei de recuperação de empresas e falência. p. 152 e ss.

20 TOLEDO, Paulo Fernando Campos Salles de. "Disposições preliminares". In: TOLEDO, Paulo Fernando Campos Salles de; ABRÃO, Carlos Henrique (Coord.). Comentários à Lei de recuperação de empresas e falência. p. 56. 
Especificamente sobre o instituto da recuperação, Mauro Rodrigues Penteado externa que as cooperativas não podem se beneficiar da recuperação de empresas. ${ }^{21}$

Waldo Fazzio Júnior afirma que as sociedades cooperativas estão fora do campo de abrangência Lei n. 11.101/2005, sendo regidas pelo Código Civil e Lei n. 5.764/1971, pois seu escopo é promover benefícios a seus associados, não tendo objetivo lucrativo, sendo que a necessidade de praticar eventuais condutas próprias de empresas, no desempenho de suas atividades, não altera seu perfil. ${ }^{22}$

Vera Helena de Mello Franco e Rachel Sztajn afirmam que as cooperativas como espécies de sociedades simples não estão abrangidas pela Lei n. 11.101/2005. ${ }^{23}$

Haroldo Malheiros Duclerc Verçosa afirma que a sociedade cooperativa acabou tendo uma natureza jurídica híbrida, ou seja, está entre a sociedade simples e a sociedade empresária. Sendo que do ponto de vista econômico as cooperativas são empresas, pois colocam no mercado bens e serviços, podendo neste caso serem tidas como sociedades empresárias, acomodando-se perfeitamente ao conceito de empresário previsto no art. 966 do Código Civil; e, consequentemente, no art. $1^{\circ}$ da Lei n. 11.101/2005, lembrando que o art. $2^{\circ}$ dessa lei exclui apenas às cooperativas de crédito. ${ }^{24}$

Contudo, entendemos que o instituto da recuperação de empresas pode ser aplicado às cooperativas em geral (exceto às cooperativas de crédito) quando desenvolverem atividade empresarial e em razão do princípio da preservação da empresas (que visa a manutenção dos empregos, o recolhimento de tributos etc.). Porém, as cooperativas não se submetem à falência, mas sim a liquidação extrajudicial por força da exclusão do art. $4^{\text {o }}$, caput, da Lei n. 5.764/71; podendo, se for o caso, na liquidação extrajudicial aplicar-se subsidiariamente as regras de liquidação das instituições financeiras e a norma falimentar.

\subsection{Recuperação especial das microempresas e empresas de pequeno porte}

As diretrizes que determinam o que é microempresa e empresa de pequeno porte estão na Lei Complementar - LC n. 123/2006 - Estatuto Nacional da Microempresa e da Empresa de Pequeno Porte. Conforme a Lei Complementar n. 123/2006, microempresa (ME) é aquela que possui receita bruta anual de até R $\$ 360$ mil por ano (art. $3^{\circ}$, inc. I). Por sua vez, empresa de pequeno porte (EPP) é aquela que possui receita bruta anual superior

21 PENTEADO, Mauro Rodrigues. "Disposições preliminares". In: SOUZA JUNIOR, Francisco Satiro; PITOMBO, Antônio Sérgio A. de Moraes (Coord.). Comentários à lei de recuperação de empresas e falência: Lei 11.101/2005. São Paulo: Revista dos Tribunais, 2005. p. 110.

22 FAZZIO JÚNIOR, Waldo. Lei de falência e recuperação de empresas. p. 33/34.

23 FRANCO, Vera Helena de Mello; SZTAJN, Rachel. Falência e recuperação da empresa em crise. Rio de Janeiro: Elsevier, 2008. p. 20.

24 Haroldo Malheiros Duclerc Verçosa. Das pessoas sujeitas e não sujeitas aos regimes de recuperação de empresas e ao da falência. In: PAIVA, Luiz Fernando Valente de (Coord.). Direito falimentar e a nova lei de falências e recuperação de empresas. p. 109/110. 
a R\$ 360 mil até o limite de R\$ 3.600 mil (art. $3^{\circ}$, inc. II).Lembre-se sempre de que o que irá caracterizar o empresário como micro ou pequeno é a receita bruta que ele auferir em cada ano.

A Lei de Recuperação e de Falência prevê a possibilidade de a microempresa e da empresa de pequeno porte obter o benefício da recuperação judicial, mediante a apresentação de um plano especial de recuperação (LRF, art. 70). É denominado plano especial, pois a recuperação para ME e EPP é muito mais simples de se concretizar, liberando o empresário de certas exigências feitas para a recuperação convencional. Por isso, alguns chamam a recuperação da ME ou EPP de recuperação especial de empresa.

Em geral, a recuperação judicial da microempresa e de empresa de pequeno porte segue a sistemática da recuperação judicial "convencional”, ressalvados alguns aspectos, a saber. Trata-se de uma ação judicial, que começa pela petição inicial, com a figura do administrador judicial e do comitê de credores, assim como ocorre com a recuperação judicial "convencional".

É bom salientar que na petição inicial deve ficar claro que o empresário pleiteia a recuperação especial para ME ou EPP, pois do contrário, poderá o juiz entender que ele deseja a recuperação judicial ordinária, uma vez que esta, em tese, é possível também a ME ou EPP. Mas neste caso, precisará atender aos requisitos que são próprios da recuperação ordinária/convencional.

O plano especial de recuperação da microempresa e da empresa de pequeno porte, no entanto, fica limitado às seguintes condições, que o diferenciam (LRF, art. 71): 1) abrangerá exclusivamente créditos quirografários (comuns sem garantias ou privilégios); 2) parcelamento limitado a trinta e seis prestações mensais, com valores iguais e sucessivos, corrigidos monetariamente e acrescidos de juros de $12 \%$ ao ano; 3) o pagamento da primeira parcela deverá ser pago em até cento e oitenta dias, contados da distribuição da petição inicial; 4) após ouvir o administrador judicial e o comitê de credores, o devedor não pode aumentar suas despesas ou contratar empregados sem autorização judicial.

Não há suspensão da prescrição, nem das ações e execuções contra o devedor por créditos não abrangidos pelo plano, ou seja, créditos não quirografários como os trabalhistas e os com garantias reais (LRF, art. 71, parágrafo único). Por isso, apenas quanto aos créditos quirografários alcançados no plano especial de recuperação é que existe essa suspensão da prescrição, das ações e das execuções. Os demais credores poderão cobrar seus créditos normalmente, na via judicial ou extrajudicial.

Além disso, não existe a necessidade de convocar assembleia-geral de credores para decidir sobre o plano especial de recuperação judicial da microempresa e da empresa de pequeno porte. O juiz concederá esse benefício legal verificando apenas se as exigências legais estão sendo atendidas (LRF, art. 72, caput). Além disso, o juiz julgará improcedente o pedido de recuperação, decretando a falência da microempresa e da 
empresa de pequeno porte, se houver objeções (oposição, impedimento, contestação) dos credores de mais da metade dos créditos quirografários (LRF, art. 72, parágrafo único). Também, poderá haver a convolação da recuperação especial, aqui tratada, em falência caso haja descumprimento do plano de recuperação. Nesse sentido:

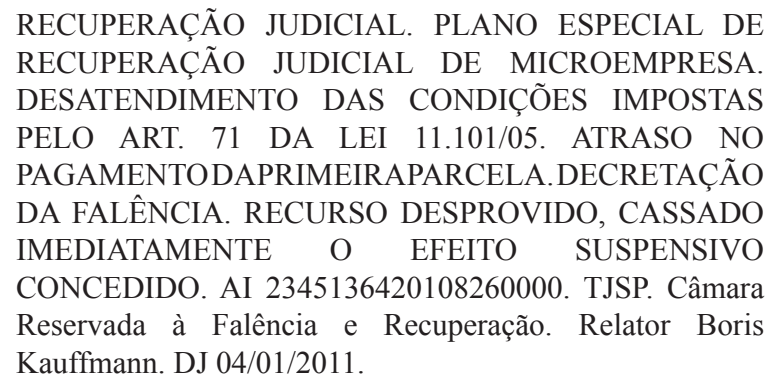

Feitas estas considerações acerca da recuperação especial para microempresas e empresas de pequeno porte, passa-se a seguir ao exame, ainda que sucinto, do direito estrangeiro sobre a recuperação de empresas.

\subsection{Direito estrangeiro}

Em linhas gerais, este item visa demonstrar que a legislação brasileira quanto à recuperação judicial de empresas inspirou-se em modelos adotados primeiramente em outros países, mas não necessariamente tem-se por escopo aqui fazer um estudo de direito comparado, por escapar do foco deste trabalho. As informações a seguir foram, em parte, a partir de exposições do Prof. Paulo Fernando Campos Salles de Toledo, bem como de artigo de autoria do mesmo professor: "Recuperação judicial, a principal inovação da Lei de Recuperação de Empresas - LRE". ${ }^{25}$

Os Estados Unidos foram quem primeiro disciplinou o instituto da recuperação de empresas, desde 1938, mas com substancial avanço e inovações em 1978 com a norma de reforma falimentar, a qual consolidou o princípio da reorganização empresarial, cujo processo de reorganização, de iniciativa do devedor ou dos credores, visa criar condições para preservação de empresas economicamente viáveis. Vale destacar que na recuperação judicial americana todos os credores podem ser abrangidos e o devedor é mantido na gestão do negócio. Neste país, fundamentalmente, se busca criar possibilidade para a negociação direta entre devedor e credores.

A França foi o primeiro país europeu a cuidar da matéria, especialmente a partir de 1985 em que a recuperação de empresas surgiu com a finalidade de salvar

25 TOLEDO, Paulo Fernando Campos Salles de. Recuperação judicial, a principal inovação da Lei de Recuperação de Empresas - LRE. Revista do Advogado, São Paulo, n. 83, p. 98-106, 2005. 
a empresa, manter os empregos, bem como promover o pagamento dos credores. Além da recuperação empresarial para empresas que tenham contra si configurada, e como pressuposto, a cessação de pagamentos, existe o instituto da salvaguarda, um remédio judicial preventivo que consiste em um período de observação que precede a cessão dos pagamentos, visando assim uma reorganização antes mesmo do inadimplemento das obrigações. Trata-se efetivamente de um mecanismo preventivo a possíveis crises.

Já na Alemanha, a recuperação de empresas foi objeto de reforma em 2011, a qual buscou simplificar as regras para o plano de insolvência, que deve ser apresentado em até três meses do ajuizamento e aprovado pelos credores. Além disso, se permiti a inclusão de sócios ou acionistas como credores neste plano, bem como se prevê a manutenção do dirigente na gestação do negócio. A lei alemã tem um caráter pró-credor e adota como pressuposto a cessão de pagamentos para fins de concessão da recuperação de empresas.

Por sua vez, Portugal tem um Código de Insolvência e Recuperação de Empresas, datado de 2004, o qual também tem um caráter favorável aos credores, por inspiração na norma alemã. A lei portuguesa prevê que o plano de recuperação deve ser aprovado por assembleia-geral de credores e homologado por juiz, que controlará a legalidade do plano e de sua aprovação, podendo não homologá-lo se for manifestamente inexequível.

Convênio é a denominação adotada pela Espanha, que consiste no acordo entre devedor e credores, cuja norma disciplinadora data de 2003, com vigência a partir de 2004 e reformas posteriores. O convênio é equivalente à recuperação judicial de empresas, com participação dos credores por meio de assembleia-geral (não previsão de comitê de credores) e que depende de aprovação judicial.

Também a Itália, substancialmente a partir 2005, visa reestruturar as empresas em crise por meio do instituto da concordata preventiva e suspensiva (ou falimentar). A concordata preventiva, que se assemelha com a recuperação judicial brasileira, visa superar a crise e impedir a falência da empresa, sendo que o plano de reestruturação da empresa deve ser submetido à assembleia-geral de credores, que deverá aprová-lo por maioria em cada classe de credores. Já a concordata suspensiva visa conceder uma segunda chance no curso do processo falimentar de uma empresa.

Especialmente a partir 1986, e com reforma legislativa posterior, o Reino Unido buscou dar tratamento a recuperação judicial de empresas, encorajando-a e buscando reduzir os processos de liquidação. No fundo, cuida-se de um acordo entre devedor e credores para empresas em dificuldade, mas que são viáveis economicamente, sendo que o acordo também pode ser promovido a fim de favorecer indivíduos que perigam ter sua falência pessoal decretada por dificuldades financeiras.

Desde 1992, mas com reforma em 2011, a Argentina disciplina a recuperação de empresas por meio dos institutos do concurso judicial e concurso extrajudicial, 
que guardadas as devidas peculiaridades, equivaleriam a nossa recuperação judicial e extrajudicial, respectivamente. A norma tem como pressuposto a cessão de pagamentos, cabendo inicialmente ao devedor apresentar o plano de recuperação, não o fazendo poderá ser feito pelos credores.

\section{Conclusão}

Fundamentalmente, este artigo teve por objeto o exame do instituto da recuperação judicial de empresas, a partir da posição da doutrina empresarialista brasileira cotejado com as disposições da Lei n. 11.101/2005 - Lei de recuperação empresas e falência -, além do apoio na jurisprudência dos tribunais pátrios.

Inicialmente, para formar bases à pesquisa, fez-se uma contextualização da recuperação de empresas como gênero do qual a recuperação judicial e extrajudicial são espécies. Também pode-se relembrar algumas das peculiaridades da concorda suspensiva e preventiva, a fim de compreender que, no Brasil, a recuperação judicial, no fundo, é uma evolução da concordata, ora revogada pela Lei n. 11.101/2005. Foi importante tratar do que vem a ser crise empresarial e suas causas e do princípio da preservação da empresa, que tem sido o grande norteador da doutrina e jurisprudência brasileiras, especialmente quando se trata de firmar-se no sentido da prevalência do interesse coletivo em detrimento de interesses individuais.

Num segundo momento, fez-se a análise do regime jurídico da recuperação judicial, passando pelos aspectos de sua natureza, pressupostos, créditos abrangidos, requisitos e meios de recuperação, para aí examinar o plano de recuperação e sua viabilidade econômica. Percebeu-se pela análise que, a norma concursal brasileira evolui nesta matéria de reorganização da atividade empresarial acompanhando o que vem sendo adotado há algum tempo por diversos países, como Estados Unidos, França, entre outros. Viu-se que no Brasil é possível a aprovação do plano de recuperação pelo juiz, mesmo não havendo a aprovação pela assembleia-geral de credores por meio do cram down, assim como previsto pela lei norte-americana.

Contudo, entende-se que no Brasil a legislação concursal evolui quanto à reorganização da atividade empresarial, especialmente pela revogação da concordata e a criação da recuperação judicial de empresas, haja vista que esta é muito mais ampla em suas possibilidades de reerguimento da empresa. A norma visa fundamentalmente a preservação da empresa, não tendo necessariamente um caráter apenas pró-devedor ou pró-credor, mas sim um viés em favor da sociedade em geral, ao se pretender eliminar a crise econômico-financeira da atividade empresarial e, consequentemente, manter a fonte produtiva, os empregos e os interesses dos credores.

São Paulo, agosto de 2012. 


\section{Referências}

BENETI, Sidnei Agostinho. O processo de recuperação judicial. In: PAIVA, Luiz Fernando Valente de (Coord.). Direito falimentar e a nova lei de falências e recuperação de empresas. São Paulo: Quartier Latin, 2005.

BEZERRA FILHO, Manoel Justino. Nova lei de recuperação e falências comentada. 3. ed. São Paulo: RT, 2005.

COELHO, Fábio Ulhoa. Comentários à lei de falências e de recuperação de empresas. 8. ed. São Paulo: Saraiva, 2011.

. Curso de direito comercial: direito de empresa. 8. ed. São Paulo: Saraiva, 2008, v. 3.

FAZZIO JÚNIOR, Waldo. Lei de falência e recuperação de empresas. 4. ed. São Paulo: Atlas, 2008.

FRANCO, Vera Helena de Mello; SZTAJN, Rachel. Falência e recuperação da empresa em crise. Rio de Janeiro: Elsevier, 2008.

MAFFIOLETTI, Emanuelle Urbano. O direito concursal das sociedades cooperativas e a lei de recuperação de empresas e falência. Tese (Doutorado em Direito) - Faculdade de Direito da Universidade de São Paulo, São Paulo, 2010.

LOBO, Jorge. Da recuperação judicial. In: TOLEDO, Paulo Fernando Campos Salles de; ABRÃO, Carlos Henrique (Coord.). Comentários à Lei de recuperação de empresas e falência. 4. ed. São Paulo: Saraiva, 2010.

PAIVA, Luiz Fernando Valente de. Apresentação do plano de recuperação pelo devedor e a atuação dos credores. Revista do Advogado, n. 83, São Paulo, 2005.

PENTEADO, Mauro Rodrigues. Disposições preliminares. In: SOUZA JUNIOR, Francisco Satiro; PITOMBO, Antônio Sérgio A. de Moraes (Coord.). Comentários à lei de recuperação de empresas e falência: Lei 11.101/2005. São Paulo: RT, 2005.

PINHEIRO, Armando Castelar; SADDI, Jairo. Direito, economia e mercados. Rio de Janeiro: Elsevier, 2005.

SANTOS, Paulo Penalva. Os contratos na recuperação judicial e na falência”. In: PAIVA, Luiz Fernando Valente de (Coord.). Direito falimentar e a nova lei de falências e recuperação de empresas. São Paulo: Quartier Latin, 2005.

SZTAJN, Rachel. "Da recuperação judicial”. In: SOUZA JUNIOR, Francisco Satiro; PITOMBO, Antônio Sérgio A. de Moraes (Coord.). Comentários à lei de recuperação de empresas e falência: Lei 11.101/2005. São Paulo: RT, 2005.

Teoria jurídica da empresa: atividade empresária e mercados. 2. ed. São Paulo: Atlas, 2010.

TEIXEIRA, Tarcisio. Direito empresarial sistematizado: doutrina e prática. São Paulo: Saraiva, 2011. 
. Curso de direito e processo eletrônico: doutrina, jurisprudência e prática. São Paulo: Saraiva, 2012.

TOLEDO, Paulo Fernando Campos Salles de. Disposições preliminares. In: TOLEDO, Paulo Fernando Campos Salles de; ABRÃO, Carlos Henrique (Coord.). Comentários à Lei de recuperação de empresas e falência. 4. ed. São Paulo: Saraiva, 2010.

. Recuperação judicial, a principal inovação da Lei de Recuperação de Empresas - LRE. Revista do Advogado, São Paulo, n. 83, 2005.

VERÇOSA, Haroldo Malheiros Duclerc Verçosa. Das pessoas sujeitas e não sujeitas aos regimes de recuperação de empresas e ao da falência. In: PAIVA, Luiz Fernando Valente de (Coord.). Direito falimentar e a nova lei de falências e recuperação de empresas. São Paulo: Quartier Latin, 2005.

. Prefácio do livro de Vera Helena de Mello Franco e Rachel Sztajn. Falência e recuperação da empresa em crise. Rio de Janeiro: Elsevier, 2008. 